\title{
Understanding Perceptions of Health Risk and Behavioral Responses to Air Pollution in the State of Utah (USA)
}

\author{
Tabitha M. Benney ${ }^{1, *(\mathbb{D})}$, Devon Cantwell ${ }^{2}{ }^{\mathbb{D}}$, Phillip Singer ${ }^{1,3}$, Linda Derhak $^{1}$, Samuel Bey ${ }^{4}$ and Zahra Saifee ${ }^{4}$ \\ 1 Department of Political Science, University of Utah, Salt Lake City, UT 84112, USA; \\ phillip.singer@poli-sci.utah.edu (P.S.); derhaklinda@gmail.com (L.D.) \\ 2 Department of Political Studies, University of Ottawa, Ottawa, ON K1N 6N5, Canada; dcant074@uottawa.ca \\ 3 Health Society and Policy, University of Utah, Salt Lake City, UT 84112, USA \\ 4 Environmental and Sustainability Studies, University of Utah, Salt Lake City, UT 84112, USA; \\ samuelliott96@gmail.com (S.B.); zahrasaifee24@gmail.com (Z.S.) \\ * Correspondence: tabitha.benney@poli-sci.utah.edu
}

Citation: Benney, T.M.; Cantwell, D.; Singer, P.; Derhak, L.; Bey, S.; Saifee, Z Understanding Perceptions of Health Risk and Behavioral Responses to Air Pollution in the State of Utah (USA). Atmosphere 2021, 12, 1373. https://doi.org/10.3390/ atmos12111373

Academic Editor: Anil Namdeo

Received: 15 September 2021

Accepted: 14 October 2021

Published: 20 October 2021

Publisher's Note: MDPI stays neutral with regard to jurisdictional claims in published maps and institutional affiliations.

Copyright: (c) 2021 by the authors. Licensee MDPI, Basel, Switzerland This article is an open access article distributed under the terms and conditions of the Creative Commons Attribution (CC BY) license (https:// creativecommons.org/licenses/by/ $4.0 /)$

\begin{abstract}
Poor air quality in Utah creates an array of economic, environmental, and health-related impacts that merit investigation and informed political responses. Air pollution is known to cause a variety of health problems, ranging from increased rates of asthma to cardiovascular and lung disease. Our research investigates the extent of Utahn's understanding of the health risks associated with long-term and short-term impacts of air quality. To assess the degree to which Utahn's perceive the health risks of air pollution, we performed an ordinal logistic regression analysis using responses to the Utah Air Quality Risk and Behavioral Action Survey, a representative panel survey administered between November 2018 and January $2020(n=1160)$, to determine how socioeconomic status impacts risk perception. Socioeconomic status is not a predictor of perceiving air's short-term risks to health. Those with more conservative political orientation, as well as those with higher religiosity scores, were less likely than those with more liberal political orientation or those with lower religiosity scores to strongly agree that air pollution poses short-term health risks. We find that for short-term health risks from air pollution, Utahns in the middle-income category are more likely than those in the low-income category to strongly agree that air pollution poses long-term health risks. In addition, those with more conservative political orientation were less likely than those with more liberal political orientation to strongly agree that air pollution poses long-term health risks.
\end{abstract}

Keywords: risk perception; health risks; air pollution; socioeconomic status; education; long-term; short-term; air quality; Utah; Salt Lake City; high income; low income; misperceptions of pollution

\section{Introduction}

Although Utah is renowned for its majestic natural sites, the air quality throughout the state can vary dramatically throughout the year. The air quality in Utah's urban centers, which are all located in topographical basins that trap air pollution, varies significantly [1,2]. Salt Lake County, the most populous region in the state, is located at the intersection of four major highways (I-80, I-15, I-215, and U.S. 89), and traffic density and congestion in the county has increased by ten percent or more annually in recent years [3], making the area increasingly susceptible to transportation related air pollution. According to the American Lung Association, Salt Lake City, UT (USA) ranks 8th nationwide for ozone and 17th for $24 \mathrm{~h}$ particle pollution [4]. As a result, the social, economic, and political consequences of air pollution in the state can be significant. Despite this, the public's perceptions of risk around air quality remains a serious, and unexplored, issue in the state.

\subsection{Impacts of Air Pollution}

In Utah, air pollution has traditionally been generated by local sources, including transportation, wood burning, and industry emissions, which result in unhealthy levels 
of ozone and particulate matter, especially $\mathrm{PM}_{2.5}$. While ozone plagues the populations at higher elevations, $\mathrm{PM}_{2.5}$ is a serious issue in lower elevations of the state. While the American Lung Associate suggests healthy cities maintain less than 3.2 days of high particle pollution per year on average (i.e., $35.5 \mu \mathrm{g} / \mathrm{m}^{3}$ or higher in a $24-\mathrm{h}$ period), in Salt Lake County, the average number of high particle pollution days per year was 7.5, with the city of Salt Lake City experiencing 9.2 days of high particle pollution on average for the years 2017-2019 [5]. In addition, exposure to $\mathrm{PM}_{2.5}$ pollution, even at lower levels, is linked to a wide range of diseases such as heart and pulmonary disease and can be particularly harmful because of its smaller particle size. At only 2.5 micrometers, $\mathrm{PM}_{2.5}$ particles are able to travel deeply into the lungs, where they may enter the bloodstream [6]. $\mathrm{PM}_{2.5}$ can also affect the environment by reducing crop productivity, lengthening growing cycles, or creating haze, which can reduce visibility [7]. These particles are also known to make lakes and streams acidic and change the nutrient balance in bodies of water, which in turn directly impacts the local environment [8].

Air pollution has a wide variety of impacts on society, but is especially harmful for human health and well-being. Recent studies provide increasing evidence that air pollution contributes to a range of illnesses including asthma, COPD, heart disease, pneumonia, depression, low birth weight, and increased mortality [9-17]. Children and vulnerable populations are at the greatest risks from the impacts of air pollution due to structural and biological reasons $[18,19]$. Children are at a high risk of pollution-related disease and even very low-dose exposures to pollutants in early infancy can result in disease, disability, and death in childhood and across their lifespan [18]. Air pollution has also been found to adversely affect healthy brain development in children [20]. Children are also more sensitive to pollutants due to their increased respiration in comparison to body size, undeveloped respiratory and immunologic systems, low metabolic capacity, and longer life expectancy compared to older populations [8].

People with preexisting health conditions, such as heart and lung diseases, are also especially vulnerable to air pollution. Chronic Obstructive Pulmonary Disease (COPD), which is the third leading cause of death in the United States, encompasses certain lung diseases such as asthma, chronic bronchitis, and emphysema. COPD is the third leading cause of death in the United States [21]. The main cause of COPD is smoking, but inhaling air pollutants has a similar effect, with increased rates of the disease being tied to prolonged exposure to poor air quality. In Utah, about $4 \%$ of adults have been diagnosed with COPD, and the prevalence of asthma has doubled in the past 30 years in both adults and children [8]. Air pollution is a common asthma trigger since it irritates and damages airways. Heart disease is also exacerbated by air pollutants, as increased levels of air pollutants are associated with increased hospitalization and death due to heart disease. This is because, when inhaled, pollutants can cause inflammation and an imbalance of pro- and anti-oxidants in cell functions, called oxidative stress, which can then lead to arrhythmia or a heart attack [22].

Finally, air pollution has lasting environmental impacts. Utah's unique geographic context exacerbates winter and summertime air quality conditions, as the cities' location within a topographic bowl created by two mountain ranges allows for a buildup of pollutants in the air through thermal inversions and deterrents to storms and winds. The resulting smog that is common to urban environments situated in small-basin geographies (such as Salt Lake City or Beijing) have cascading consequences for ecological systems. An extensive body of research has been conducted to analyze how fresh snow is affected by the accumulation of particulate matter generated from surrounding metropolitan areas. Snow analysis in the Utah Mountains has revealed elevated ion concentrations of sodium, $\mathrm{Cl}-$, $\mathrm{NH} 4+$, and $\mathrm{NO}_{-}-$in response to wintertime pollution events [23]. The increasing levels of these ions into mountain ecosystems are of concern regarding their capacity to impact water quality as well as the functioning of sensitive biotic systems. Furthermore, soot generated from the incomplete combustion of fossil fuels is deposited at high elevations, decreasing snow surface albedo which, in turn, increases rates of snowmelt [24]. 
The lowered reflectance potential of the snow in combination with rising average temperatures exacerbates snowpack melt and runoff throughout the winter seasons. Such compounding stressors complicate water supply management and increase flood hazards in the valleys below.

Despite growing interest and awareness about the dangers of air pollution, more than 141 million people in the U.S. live in counties with unhealthy levels of air pollution and traffic congestion, with economically disadvantaged populations facing disproportionate levels of exposure to such pollutants [25]. This has largely been attributed to lifestyle factors and exposure over the life cycle, which are often attributed to three main factors: income, education, and occupation [26]. Income is closely tied to levels of health care, but may also impact nutrition, housing, schooling, and stress reducing leisure activities. Although the association between income and health is stronger at lower incomes, income effects persist above the poverty level [27]. Subsequently, it is well established that income level is predictive of mortality rates in all Western societies [28-31]. Likewise, the quality and extent of education available in society is also predictive of future occupational opportunities and earning potential. Education also teaches basic life skills and allows individuals to access information that can greatly contribute to long term health outcomes. For instance, Winkleby et al. (1992) studied how education, income, and occupation relate to risk factors for cardiovascular disease, but found education to be the only significant predictor of this outcome [32]. Finally, occupation can also contribute to health in some consequential ways. Proximity to stationary pollution sources [33] and exposure to toxins in the work place have been associated with negative health outcomes [34,35] and can also have generational effects [36]. High stress/high risk occupations are also important contributing factors for morbidity and reduced immune health [25]. As a result, pollutant exposure rates in the US are more likely determined by socioeconomic status than any other factor $[25,37,38]$.

These factors can be included in social determinants of health which play an important role in health outcomes. The World Health Organization defines them as, " ... the nonmedical factors that influence health outcomes. They are the conditions in which people are born, grow, work, live, and age, and the wider set of forces and systems shaping the conditions of daily life" [39]. Differences in these conditions can lead to health disparities. Health disparities are defined as a "particular type of health difference that is closely linked with social, economic, and/or environmental disadvantage" [40]. The United States launched Healthy People 2010 with the goal of eliminating health disparities, updating it in 2020 to achieve health equity. Healthy People 2020 includes clean water and non-polluted air as determinants essential for good health. Research shows how air pollution can create health disparities, such as children in the United States living below the poverty line being 56 percent more likely to have asthma than children with family incomes at or above 400 percent of the poverty threshold [41].

Furthermore, shortfalls in medical care account for ten percent of early deaths, with genetic predispositions accounting for 30 percent, social circumstances 15 percent, environmental exposures 5 percent, and behavioral patterns 40 percent [42]. It is established that it is not these factors working independently that can cause an early death, rather, it is them working together. Environmental exposures or behaviors can cause a gene to be expressed, or social conditions can impact what health care an individual has access to [42]. The emergence of the exposome paradigm has also traced the ways that exposure to human environmental conditions, such as air pollution, can modify the genetic profiles of individuals over the course of their life [43].

This uneven exposure to environmental risks and hazards is called environmental inequality, and it is created by social, economic, and political processes that worsen economic and social inequality. This form of inequality exposes already disadvantaged populations to the increased harms that go well beyond simple health outcomes. For example, a recent U.S. study found that pregnant women exposed to high temperatures or air pollution are more likely to have children who are premature, underweight, or stillborn, and the effects hurt Black mothers and babies the most [25]. Additional research has found disparities as- 
sociated with air quality and socioeconomic status, language minority status, immigration status, race, and ethnicity [44]. Now, emerging research suggests that patients with severe COVID-19 are twice as likely to have had pre-existing respiratory diseases and three times as likely to have had cardiovascular problems [45], thus severely compounding concerns over this relationship.

\subsection{Risk Perception}

Despite the well-established issues with air quality, public perceptions of air pollution often fail to take these risks into account. As a result, support from constituents to make effective and durable public policy in this domain is lacking. For example, Shin et al. (2019) surveyed 4033 participants across the United States and reported that only roughly $40 \%$ of respondents felt that health impacts were related to environmental issues. People tend to have a favorable view of their own neighborhoods compared to the cities outside of them, known as the "halo effect" [46]. People perceive their neighborhood as less polluted than their cities, regardless of the actual level of pollution. These perceptions impact behavioral and lifestyle choices that contribute to air pollution.

Public perceptions of air pollution and the associated health risks are influenced by three key factors: psychological makeup of individuals, social characteristics of individuals, and the environmental conditions in which individuals live, including pollution exposure [47]. Bickerstaff (2004) explores how risk perception is derived from social and cultural experiences of everyday life by synthesizing psychological literature on risk perception with recent socio-cultural analyses of perceptions of air pollution. Bickerstaff found that those with more power and greater socioeconomic status are likely to have lower risk perceptions because they perceive the world as less dangerous. Wealthier communities also felt poor health resulting from air pollution was a problem associated with impoverished communities' proximity to heavy industry. Political and economic marginalization intensified personal concern of air pollution problems [48].

\subsection{Hypotheses}

To better understand how income may impact perceptions of air quality on the shortand long-term health risks of air pollution, we propose the following hypotheses.

Hypothesis 1 (H1). Utahns with higher socio-economic status will have lower perceived risk of health impacts related to air pollution.

Hypothesis 1 (H1a). The higher the socio-economic status, the lower the perceived risk of air pollution impacts on short-term health.

Hypothesis 1 (H1b). The higher the socio-economic status, the lower the expected perceived risk of air pollution impacts on long-term health.

Research has found that those with more power and greater socioeconomic status are likely to have lower risk perceptions because they perceive the world as less dangerous [48]. Since they have a greater socioeconomic status and power, they perceive that they can make a difference, which also lowers the risk perception. It has also been shown that those with a higher socio-economic status are less likely to be exposed to air pollutants from major roadways and industrial facilities [49]. Since these individuals do not live in these areas, they are likely to think the health risks of air pollution do not impact them the same as others.

Hypothesis 2 (H2). Utahns with lower socio-economic status will have higher perceived risk of health impacts related to air pollution.

Hypothesis 2 (H2a). The lower the socio-economic status, the higher the perceived risk of air pollution impacts on short-term health. 
Hypothesis $\mathbf{2}(\mathbf{H} \mathbf{2 b})$. The lower the socio-economic status, the higher the expected perceived risk of air pollution impacts on long-term health.

It is known that those with a lower socio-economic status have a higher exposure to air pollutants since they may live closer to roadways and polluting industrial facilities, due to property values reflecting these prevailing pollution regimes [49]. Due to this higher exposure, these impoverished and often underrepresented communities are more likely to have health related impacts because of air pollution. Individual perceptions of risk are correlated with the frequency and intensity of people's experiences with various hazards, including air pollution [48]. Because of this correlation, those who have been negatively impacted by air pollution-related problems in the past are going to be more likely to present higher levels of health risk perception compared to those less affected by air pollution.

\subsection{Alternative Hypotheses}

\subsubsection{Religion and Religiosity}

In addition to the ways in which income can influence perceptions of air pollution, we also explore the ways which religion and religiosity are connected with the view of pollution. Utah is a unique case for understanding these connections because of the religious nature of the state and its population. Utah has the highest percentage of individuals that attend worship services at least weekly in the United States [50], as well as one where more than half the population identify themselves as "very religious" [51].

Prior literature has outlined two primary mechanisms that connect religion with pollution and environmental concern. The first set of literatures has hypothesized that religion itself acts as a framing agent to shape and influence environmental attitudes. According to this hypothesis, religion acts as benchmark for understanding interactions between humans and the environmental, particularly in regard to the role of a deity in managing the environment. This "dominion over nature", argued by White more than fifty years ago, set forth the idea that ecological problems exist because religions view the environment as having been created to serve humankind [52]. From this idea, researchers have tested the ways in which religion shapes views on the environment, hypothesizing that religious membership is connected with less concern over the environment. Indeed, much of this research was borne out this point, particularly in fundamental religions where biblical literalism abounds [53,54]. Arbuckle and Konisky find that, in general, religion is associated with less concern with the environment, though they add more nuance, finding that views on the environment vary by sect [55].

A second set of literatures has focused on including religion as an important variable of interest within a broader environmental justice research agenda. Much of the environmental justice literature has found that disadvantaged groups, whether by class, race, ethnicity, or gender, are disproportionately exposed to harmful air pollution [56-58]. Recently, a group of scholars have hypothesized that membership in a religion and the level of religiosity (for example, frequency of attendance or participation in particular membership activities) should be included in an environmental justice framework. These scholars argue that a religious organization, particularly when there is a dominant religious group, can shape access to resources and promulgate marginalization and inequality. For example, pollution exposure in Israel $[59,60]$ as well as in the United States differs along religious lines.

\subsubsection{Political Orientation}

The literature examining political orientation and its relationship to climate change beliefs, as well as environmental risk perception, is concordant. In terms of general disposition towards climate change beliefs, conservative white males are significantly more likely than other Americans to endorse denialist views than other groups of Americans [61]. Additionally, liberal and Democrat Americans are more likely than conservatives and Republicans to report beliefs about climate change consistent with scientific literature [61]. Recent studies have also shown that political orientation moderates beliefs regarding the 
nature of climate change and the risk of climate change impacts, with more liberal political orientations correlating with a higher perceived risk of climate change $[62,63]$.

Although environmental risk has been examined as a dependent variable for political orientation, the literature does not identify how political orientation impacts the perception of the health risks of a particular environmental issue, such as air pollution. Additionally, studies that measure political orientation's relationship to environmental risk perception do not differentiate between long-term and short-term risk perception.

We used political orientation instead of party identification in this analysis because the data were collected during the Trump administration, which experienced unprecedented shifts in Republican party identification nationally [64]. In Utah, the public pushback against former Representative Jason Chaffetz and Senator Mitt Romney in favor of Trump was a rare occurrence for Republican political elites during the Trump Era. Furthermore, even though Trump won the state of Utah in the 2016 election, there was strong support for Evan McMullin, who pulled 21.5\% of the presidential votes cast. Overall, national and local trends in party identification seemed like a less reliable and stable measure of political identity than political orientation.

\section{Materials and Methods}

\subsection{Institutional Review Board Statement}

All subjects gave their informed consent for inclusion before they participated in the study. The study was conducted in accordance with the Declaration of Helsinki, and the protocol was approved by the Institutional Ethics Committee of the University of Utah (IRB_00114070).

\subsection{Dependent Variables}

To test these hypotheses, we utilized survey responses from the Utah Air Quality Risk and Behavioral Action Survey [65], a state-wide survey with a stratified sampling approach based on census demographics to assess the role of environmental attitudes and behavior on public health and public policy issues caused by poor air quality. The survey respondents are Utah citizens, aged 18 and older $(n=1160)$. We operationalized our hypothesis-related responses to two survey questions. Respondents were surveyed between November 2018 and January 2020. To test H1a and H1b, we use Likert scale responses, asking respondents whether they are "concerned about the short-term impacts of air pollution on my health". We refer to this as "short-term health" in our analysis. To test H1b and H2b, we use Likert scale responses for the question: "I am concerned about the long-term impacts of air pollution on my health". We refer to this as "long-term health" in our analysis. To see the relevant questions asked on the survey and used in this analysis, please consult Appendix A.

\subsection{Independent Variables}

\subsubsection{Income}

Survey question Q3A measures socioeconomic status using eight possible income categories, which we collapse down to three categories: low income, middle income, and high income (Table 1). Those who made less than $200 \%$ of the federal poverty levels $(\$ 25,520$ for one person in 2020) were coded into the "low income" category for our analysis, while those who made $\$ 75,000$ per year or more were coded into the "high income" category. We used an income bracket of $\$ 150,000$ or more per year for our highest income category and compared it to the lowest income category in our survey, individuals making $\$ 25,000$ or less per year. Depending on the number of individuals within a household, income classifications can fluctuate. However, Utah has the largest average household size in the nation, with 3.19 persons per household in 2016, compared to the national average of 2.65 [66]. Based on responses to the two aforementioned research questions, we performed Ordinal Logistic Regression to find the relationships between high and low income on perceptions of air pollution impacts in Utah. 
Table 1. Income Variable Categories.

\begin{tabular}{ll}
\hline Income Variable Name & Income Variable Description \\
\hline Low Income & $\$ 25,000$ or less \\
\hline Middle Income & $\$ 25,001-\$ 75,000$ \\
\hline High Income & Above $\$ 75,000$ \\
\hline
\end{tabular}

\subsubsection{Religiosity}

The religiosity measure was constructed by combining five measures regarding religious activity together. The full text of these questions and item numbers can be found in Table 2 below. The Cronbach's alpha for this constructed measure is 0.88. (Cronbach's alpha is a measure of internal consistency and helps indicate how closely related the concepts in a group/index are. It is a coefficient that indicates the internal reliability of an indexed measure.)

Table 2. Religiosity survey items.

\begin{tabular}{|c|c|c|}
\hline Survey Item Number & Question Text & Response Options \\
\hline Q34 & How often do you think about religious issues? & $\begin{array}{l}\text { Very often, Quite a bit, Moderately, Not very } \\
\text { much, Not at all }\end{array}$ \\
\hline Q35 & $\begin{array}{l}\text { To what extent do you believe that God or } \\
\text { something divine exists? }\end{array}$ & $\begin{array}{l}\text { A great deal, A lot, A moderate amount, A little, } \\
\text { None at all }\end{array}$ \\
\hline Q36 & $\begin{array}{l}\text { How often do you participate in religious } \\
\text { services? }\end{array}$ & $\begin{array}{l}\text { More than once a week, Once a week, One or } \\
\text { three times a month, A few times a year, Less } \\
\text { often, Never }\end{array}$ \\
\hline Q37 & How often do you pray? & $\begin{array}{l}\text { Several times a day, Once per day, More than } \\
\text { once a week, Once a week, One to three times a } \\
\text { month, A few times a year, Less often, Never }\end{array}$ \\
\hline Q38 & $\begin{array}{l}\text { How often do you experience situations in } \\
\text { which you have the feeling that God or } \\
\text { something divine intervenes in your life? }\end{array}$ & Very often, Often, Occasionally, Rarely, Never \\
\hline
\end{tabular}

\subsubsection{Political Orientation}

We used question Q8 from the survey to measure political orientation, which is a 10-point scale to measure the political views that people might hold. Responses on the left, scored as 0 , were extremely liberal. Responses on the right, scored as 10, were considered extremely conservative.

\subsection{Method}

To test our project hypotheses, we use an ordinal logistic regression. For both tests, the null hypothesis would result in no statistically significant differences across groups. Data processing and analysis was performed using R Version 3.6.3 software [64]. For missing data fields, we used a method of imputation called multivariate data by chained equations (mice) using the R package "mice" [67]. The reference group for this research is low income and, for the more complex models, the reference includes low religiosity and a strong liberal orientation. As Table 3 illustrates, five models are tested in this research to explore each of the independent variables alone and in combination with the outcomes specified in the hypotheses. 
Table 3. Independent variables by model.

\begin{tabular}{ccccc}
\hline Model 1 & Model 2 & Model 3 & Model 4 & Model 5 \\
\hline Income & Religiosity & Political orientation & $\begin{array}{c}\text { Income } \\
\text { Religiosity } \\
\text { Political orientation }\end{array}$ & $\begin{array}{c}\text { Income } \\
\text { Religiosity } \\
\text { Political orientation } \\
\text { Interaction effects }\end{array}$ \\
\hline
\end{tabular}

\section{Results}

\subsection{Short-Term Health}

Income was not significant in any of the five models we analyzed. Middle income and high income survey respondents had no statistically significant difference in their perceived risk of short-term health effects of air pollution. Full results can be seen in Table 4 below.

Table 4. The effects of income, religiosity, and political orientation on perception of short-term health risks from air pollution.

\begin{tabular}{|c|c|c|c|c|c|}
\hline & Model 1 & Model 2 & Model 3 & Model 4 & Model 5 \\
\hline (Intercept) & $-1.177^{* * *}$ & $-0.717^{* * *}$ & $-0.469^{* *}$ & -0.082 & 0.254 \\
\hline & $(0.000)$ & $(0.000)$ & $(0.003)$ & $(0.737)$ & $(0.620)$ \\
\hline \multirow[t]{2}{*}{ IncomeMiddle Income } & -0.195 & & & -0.091 & -0.412 \\
\hline & $(0.307)$ & & & $(0.641)$ & $(0.441)$ \\
\hline \multirow[t]{2}{*}{ IncomeHigh Income } & -0.144 & & & 0.035 & 0.367 \\
\hline & $(0.481)$ & & & $(0.868)$ & $(0.521)$ \\
\hline \multirow[t]{2}{*}{ IncomePNA } & -0.481 & & & -0.242 & 1.143 \\
\hline & $(0.248)$ & & & $(0.568)$ & $(0.420)$ \\
\hline \multirow[t]{2}{*}{ Religiosity } & & $-0.038^{* * *}$ & & $-0.027 *$ & -0.046 \\
\hline & & $(0.000)$ & & $(0.011)$ & $(0.109)$ \\
\hline \multirow[t]{2}{*}{ PolOr } & & & $-0.163^{* * *}$ & $-0.147^{* * *}$ & $-0.229 *$ \\
\hline & & & $(0.000)$ & $(0.000)$ & $(0.016)$ \\
\hline \multirow{2}{*}{ IncomeMiddle Income $\times$ Religiosity } & & & & & -0.008 \\
\hline & & & & & $(0.778)$ \\
\hline \multirow[t]{2}{*}{ IncomeHigh Income $\times$ Religiosity } & & & & & 0.001 \\
\hline & & & & & $(0.969)$ \\
\hline \multirow[t]{2}{*}{ IncomePNA $\times$ Religiosity } & & & & & -0.001 \\
\hline & & & & & $(0.991)$ \\
\hline \multirow[t]{2}{*}{ IncomeMiddle Income $\times$ PolOr } & & & & & 0.089 \\
\hline & & & & & $(0.262)$ \\
\hline \multirow[t]{2}{*}{ IncomeHigh Income $\times$ PolOr } & & & & & -0.066 \\
\hline & & & & & $(0.431)$ \\
\hline \multirow[t]{2}{*}{ IncomePNA $\times$ PolOr } & & & & & -0.255 \\
\hline & & & & & $(0.203)$ \\
\hline \multirow[t]{2}{*}{ Religiosity $\times$ PolOr } & & & & & 0.005 \\
\hline & & & & & $(0.250)$ \\
\hline Num.Obs. & 1160 & 1160 & 1160 & 1160 & 1160 \\
\hline $\mathrm{AIC}$ & 1196.9 & 1180.7 & 1159.3 & 1160.1 & 1164.9 \\
\hline $\mathrm{BIC}$ & 1217.2 & 1190.8 & 1169.4 & 1190.4 & 1230.7 \\
\hline Log.Lik. & -594.466 & -588.363 & -577.664 & -574.053 & -569.461 \\
\hline
\end{tabular}

Models 1, 2, and 3 represent each independent variable by itself. Model 4 combines all three variables. Model 5 adds interactions. ${ }^{*} p<0.05,{ }^{* *} p<0.01,{ }^{* * *} p<0.001$.

Religiosity and political orientation did, however, have statistically significant results. Religiosity was statistically significant in Model 2 (only comparing outcomes for religiosity) and Model 4 (including income and political orientation). Religiosity has an inverse relationship with assessment of short-term and long-term risk. As religiosity increases, the odds of a participant selecting "Strongly Agree" for assessment of short-term or longterm health risks decreases. There were no interaction effects with religiosity.

Political orientation had statistically significant results in Model 3 (only comparing outcomes for political orientation), Model 4 (including income and religiosity), and Model 5 (including income, religiosity, and interaction effects). Political orientation has an inverse relationship with assessment of short-term health risks. As the score for political orientation increases (indicating a more conservative political orientation), the odds of a participant selecting "Strongly Agree" for assessment of short-term health risks decreases. Figure 1 
visualizes the predicted probability of each income group selecting "strongly agree" for short-term risk from air pollution.

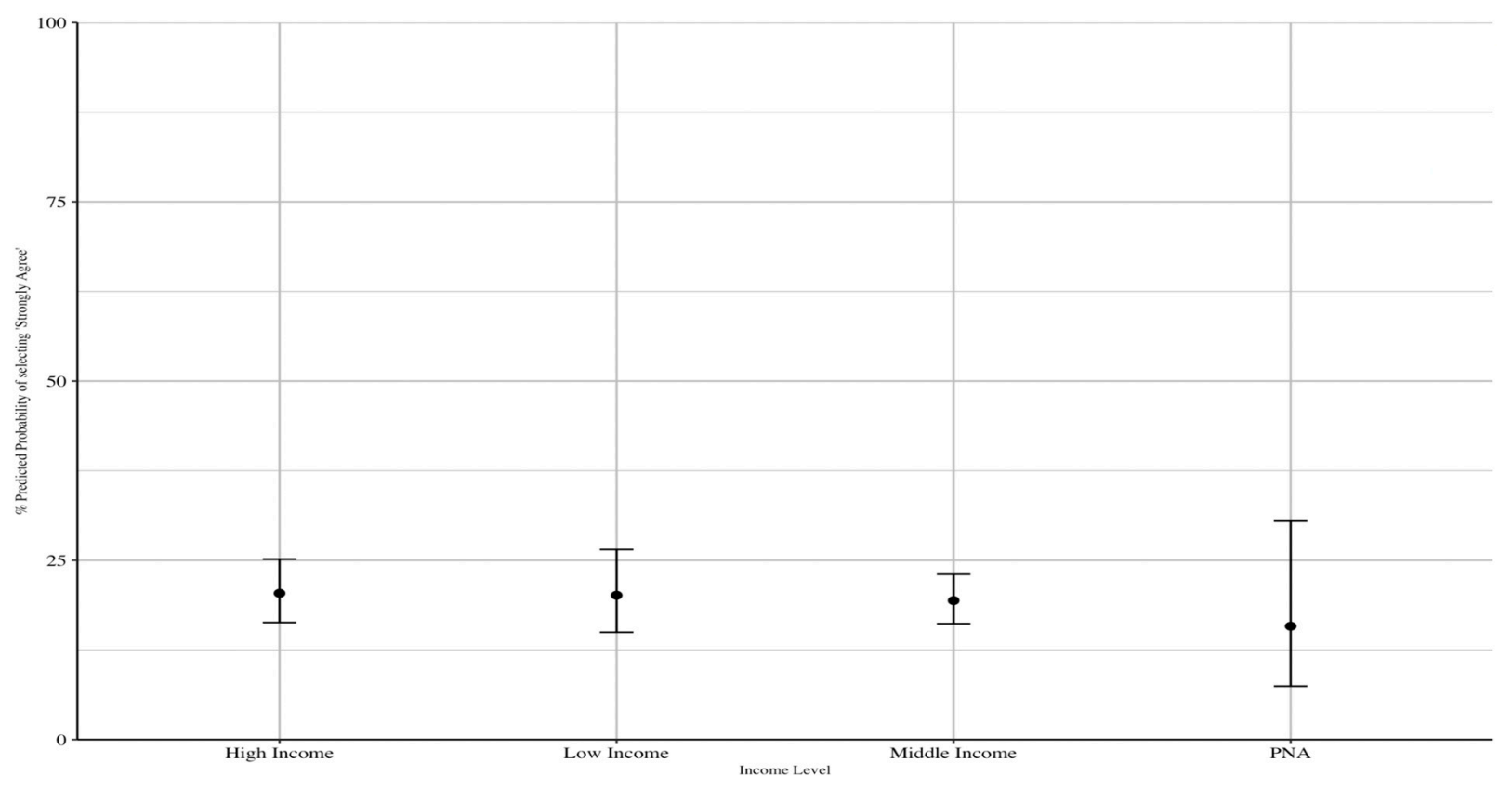

Figure 1. Predicted probability of selecting "Strongly Agree" to short-term health risks based on income level.

\subsection{Long-Term Health}

Income was significant in Model 4 (income, religiosity, and political orientation together), but only for middle income survey respondents. In this model, middle income respondents were more likely than low income respondents to strongly agree that air pollution has long-term health impacts. In Model 5, survey respondents who selected "prefer not to answer" (PNA) were statistically significant. In this model, respondents who preferred not to report their income were more likely than low income respondents to strongly agree that air pollution has long-term health impacts.

Religiosity was only statistically significant in Model 2, which only compared longterm risk identifying outcomes based on religiosity. It was not significant when income and political orientation was added to the model and it did not have any interaction effects.

Political orientation was statistically significant in Models 3 (political orientation only), 4 (all three variables), and 5 (all three variables + interaction effects). Political orientation had an inverse relationship with assessment of long-term health risks. As the score for political orientation increased (indicating a more conservative political orientation), the odds of a participant selecting "Strongly Agree" for assessment of long-term health risks decreased.

In Model 5, there was one interaction effect between respondents who preferred not to answer and had a higher value of political orientation (indicating a more conservative political orientation). Individuals who indicated both of these in their responses had lower odds of the participant selecting "Strongly Agree" for assessment of long-term health risks than low-income individuals with lower value political orientations (indicating a more liberal political orientation). Table 5 details the results of all four models. 
Table 5. The effects of income, religiosity, and political orientation on perception of long-term health risks from air pollution.

\begin{tabular}{|c|c|c|c|c|c|}
\hline & Model 1 & Model 2 & Model 3 & Model 4 & Model 5 \\
\hline (Intercept) & $\begin{array}{c}-0.754^{* * *} \\
(0.000)\end{array}$ & $\begin{array}{c}-0.351 * \\
(0.024)\end{array}$ & $\begin{array}{l}0.350 * \\
(0.015)\end{array}$ & $\begin{array}{c}0.221 \\
(0.319)\end{array}$ & $\begin{array}{c}0.354 \\
(0.466)\end{array}$ \\
\hline IncomeMiddle Income & $\begin{array}{c}0.224 \\
(0.185)\end{array}$ & & & $\begin{array}{l}0.387^{*} \\
(0.027)\end{array}$ & $\begin{array}{c}0.265 \\
(0.591)\end{array}$ \\
\hline IncomeHigh Income & $\begin{array}{l}-0.145 \\
(0.433)\end{array}$ & & & $\begin{array}{c}0.078 \\
(0.684)\end{array}$ & $\begin{array}{c}0.620 \\
(0.254)\end{array}$ \\
\hline IncomePNA & $\begin{array}{l}-0.094 \\
(0.783)\end{array}$ & & & $\begin{array}{c}0.211 \\
(0.548)\end{array}$ & $\begin{array}{l}3.496^{*} \\
(0.030)\end{array}$ \\
\hline Religiosity & & $\begin{array}{c}-0.021 * \\
(0.017)\end{array}$ & & $\begin{array}{l}-0.005 \\
(0.592)\end{array}$ & $\begin{array}{l}-0.013 \\
(0.621)\end{array}$ \\
\hline PolOr & & & $\begin{array}{c}-0.195^{* * *} \\
(0.000)\end{array}$ & $\begin{array}{c}-0.195^{* * *} \\
(0.000)\end{array}$ & $\begin{array}{c}-0.261 \text { ** } \\
(0.003)\end{array}$ \\
\hline IncomeMiddle Income $\times$ Religiosity & & & & & $\begin{array}{l}-0.011 \\
(0.667)\end{array}$ \\
\hline IncomeHigh Income $\times$ Religiosity & & & & & $\begin{array}{l}-0.020 \\
(0.468)\end{array}$ \\
\hline IncomePNA $\times$ Religiosity & & & & & $\begin{array}{l}-0.022 \\
(0.713)\end{array}$ \\
\hline IncomeMiddle Income $\times$ PolOr & & & & & $\begin{array}{c}0.058 \\
(0.420)\end{array}$ \\
\hline IncomeHigh Income $\times$ PolOr & & & & & $\begin{array}{c}-0.038 \\
(0.620)\end{array}$ \\
\hline IncomePNA $\times$ PolOr & & & & & $\begin{array}{c}-0.516 \text { * } \\
(0.031)\end{array}$ \\
\hline Religiosity $\times$ PolOr & & & & & $\begin{array}{c}0.004 \\
(0.286)\end{array}$ \\
\hline Num.Obs. & 1160 & 1160 & 1160 & 1160 & 1160 \\
\hline AIC & 1476.9 & 1474.1 & 1414.5 & 1415.3 & 1416.3 \\
\hline $\mathrm{BIC}$ & 1497.2 & 1484.2 & 1424.6 & 1445.6 & 1482.1 \\
\hline Log.Lik. & -734.471 & -735.034 & -705.268 & -701.640 & -695.173 \\
\hline
\end{tabular}

Models 1, 2, and 3 represent each independent variable by itself. Model 4 combines all three variables. Model 5 adds interactions. ${ }^{*} p<0.05,{ }^{* *} p<0.01,{ }^{* * *} p<0.001$.

Figure 2 visualizes the predicted probability of each income group selecting "Strongly Agree" for long-term risk from air pollution.

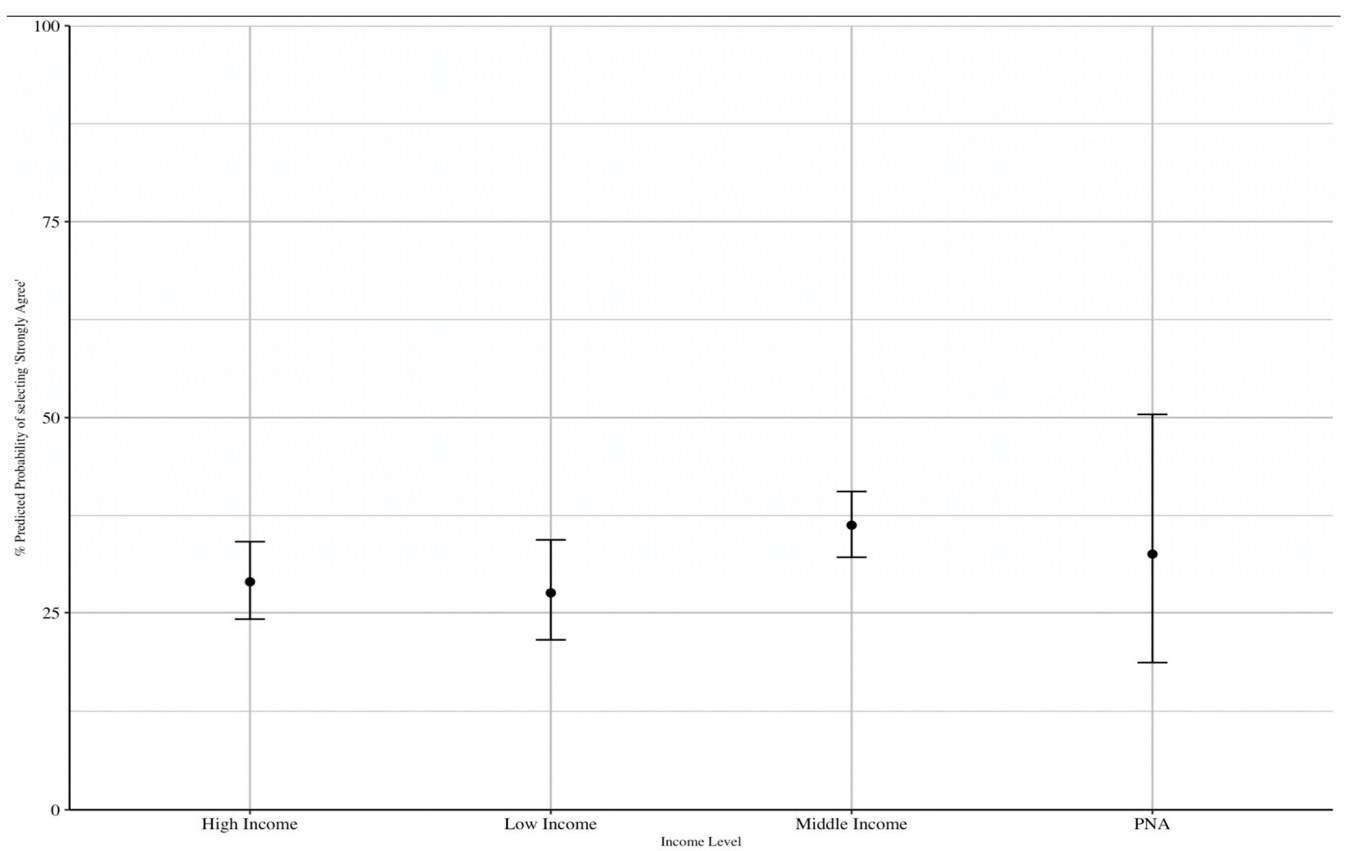

Figure 2. Predicted probability of selecting "Strongly Agree" to long-term health risks based on income level. 


\section{Discussion}

The health risks of air pollution are well documented by researchers $[8,18,20,22]$, however, there still exists a gap where citizens remain unaware of these harms. This study sought to analyze which populations of Utahns are more or less aware of the risks in order to pinpoint which groups would benefit from education and awareness efforts. When the level of risk perception is accurately known, policies and effective environmental education can be created to help align perception of risk with actual risk.

There is a gap in health risk perception research in Utah, which this study attempts to address. Since Utah, and, more specifically, the Salt Lake Valley in particular, struggles with poor air quality, it is important to know the risk perception of residents accurately to move forward with policies. Elevation is associated with differing exposure levels of air pollution, and elevation in Salt Lake Valley, in turn, is associated with income. For this reason, we researched the differences of risk perception among multiple distinct socioeconomic statuses of Utahns: those making less than $\$ 25,000$ a year and individuals making $\$ 150,000$ or more a year. We also considered the role of religion and political identity in risk assessment and how such factors may influence perceptions of air quality and other environmental issues, and found both factors to be highly influential.

As with all research, this project has some limitations. First, since the data for this research are based on an online, stratified sampling approach that closely replicates census figures, it is considered a non-probability, or opt-in, survey. While extensive effort went into addressing this issue, because it is a non-probability sample we are unable to say, with complete confidence, how representative the sample of respondents actually is in comparison to the true population of Utah. Likewise, while a wide range of factors were considered when mapping census characteristics, it is possible that factors not considered in our models are actually relevant to the dependent variable. In addition, the representativeness of the sample may also introduce bias into the research in important ways. For example, this survey only studied adults, but children make up an unusually high proportion of Utah's population. Despite this, perceptions and behaviors were not accessed as part of this study. In addition, since the survey was offered through an online format, respondents were limited to those with computer access, which is not reflective of the many rural communities in Utah. As a result of these factors, this research should be considered preliminary, and additional research will be needed to confirm these findings before further consensus can be reached on this topic.

Future research is also needed to further explore the relationship between socioeconomic status and air pollution exposure. This research could compare air quality perceptions across all income brackets to see the variation on a wider scale. Research should also be performed longitudinally to see how air quality risk perception changes over time. If policies are passed and environmental education is increased, it will be beneficial to see how perceptions of risk associated with air pollution are affected over time to ascertain the effectiveness of such efforts. Furthermore, survey analysis should incorporate spatial metrics to uncover trends in risk perception as it varies community to community. Air pollution is not spread out uniformly across areas, so it is likely health risk perception may vary across neighborhoods. Additionally, further research distinguishing between party identification and political orientation in climate risk perceptions may be informative for policymakers and public health officials. It is unclear to what extent political orientation versus party identification acts as a mediating factor in risk perception of climate change and environmental hazards.

\section{Conclusions}

Based on the results of our survey and analysis, we find that most Utahns are unaware of the long-term and short-term health risks associated with air pollution. These results are particularly discouraging as they occur within a community and state which has experienced increasingly poor air pollution in their daily lives, as well as an increased focus on pollution from government and media. Those in the highest income bracket 
$(\$ 150,000+)$ are slightly more aware than those in the lowest income bracket $(\$ 25,000$ or less annually). Although the results were not statistically significant, both groups were less likely to "strongly agree" or "agree" that air pollution causes short-term and/or longterm effects on their health than respondents from other income groups. Taken together, these results raise serious concerns about current educational and outreach efforts to help the Utah population understand the seriousness of air pollution on health.

Author Contributions: Conceptualization, T.M.B., L.D., S.B. and Z.S.; Methodology, T.M.B., D.C., L.D., S.B., Z.S.; Software, D.C.; Validation, T.M.B. and P.S.; Formal Analysis, T.M.B. and D.C.; Data Curation, T.M.B., P.S.; Writing-Original Draft Preparation, T.M.B., P.S., L.D., S.B., Z.S.; Writing— Review and Editing, T.M.B., P.S., L.D., S.B., Z.S.; Visualization, D.C.; Supervision, T.M.B.; Project Administration, T.M.B.; Funding Acquisition, T.M.B., P.S. All authors have read and agreed to the published version of the manuscript.

Funding: This research was produced as part of the Air Quality Scholars Program with support from the Global Change and Sustainability Center, University of Utah. Data collection was supported by the Interdisciplinary Exchange for Utah Science (NEXUS) Center, University of Utah and the Department of Public Health, Brigham Young University.

Institutional Review Board Statement: The study was conducted according to the guidelines of the Declaration of Helsinki, and approved by the Institutional Review Board of the University of Utah (IRB_00114070, 7/11/2018).

Informed Consent Statement: Informed consent was obtained from all subjects involved in the study.

Data Availability Statement: The data presented in this study are openly available in OpenICPSR at https:/ / doi.org/10.3886/E117904V1, accessed on 18 October 2021.

Conflicts of Interest: The authors declare no conflict of interest.

\section{Appendix A Selected Survey Questions}

Survey Questions term risk)

Q 61: Please rate your opinion about the following statements (short-term vs. long-

1. I am concerned about the short-term impacts of air pollution on my health (within $6 \mathrm{~h}$ it does damage)

2. I am concerned about the short-term impacts of air pollution on the local environment

3. I am concerned about the short-term impacts of air pollution on the local economy

4. I am concerned about the long-term impacts of air pollution on my health

5. I am concerned about the long-term impacts of air pollution on the local environment

6. I am concerned about the long-term impacts of air pollution on the local economy

Income Survey Questions:

Q3A: What was your total gross household income (e.g., income before taxes) during the past 12 months?

Control Survey Questions:

Q8: What is the highest level of school you have completed or the highest degree you have received?

Q65: What is your age?

Q36: How often do you participate in religious services?

Q59: Which of the following settings best describe where you spent the most time growing up?

Q12: What gender do you identify as?

Q73: Do you have any children? 


\section{References}

1. McDuffie, E.E.; Womack, C.C.; Fibiger, D.L.; Dube, W.P.; Franchin, A.; Middlebrook, A.M.; Goldberger, L.; Lee, B.H.; Thornton, J.A.; Moravek, A.; et al. On the contribution of nocturnal heterogeneous reactive nitrogen chemistry to particulate matter formation during wintertime pollution events in Northern Utah. Atmos. Chem. Phys. 2019, 19, 9287-9308. [CrossRef]

2. Whiteman, C.D.; Hoch, S.W.; Horel, J.D.; Charland, A. Relationship between particulate air pollution and meteorological variables in Utah's Salt Lake Valley. Atmos. Environ. 2014, 94, 742-753. [CrossRef]

3. Pishue, B. 2020 Global Traffic Scorecard; INRIX: Kirkland, WA, USA, 2020; pp. 1-23.

4. American Lung Association. State of the Air 2021; American Lung Association: Chicago, IL, USA, 2021.

5. American Lung Association Utah. State of the Air. Available online: https://www.lung.org/research/sota/city-rankings/states/ utah/salt-lake (accessed on 7 October 2021).

6. $\quad$ Nyberg, F.; Gustavsson, P.; Järup, L.; Bellander, T.; Berglind, N.; Jakobsson, R.; Pershagen, G. Urban air pollution and lung cancer in stockholm. Epidemiology 2000, 11, 487-495. [CrossRef] [PubMed]

7. Hyslop, N.P. Impaired visibility: The air pollution people see. Atmos. Environ. 2009, 43, 182-195. [CrossRef]

8. Utah Department of Health. Air Pollution and Public Health in Utah; Utah Department of Health: Salt Lake City, UT, USA, 2015.

9. Brauer, M. How Much, How Long, What, and where: Air pollution exposure assessment for epidemiologic studies of respiratory disease. Proc. Am. Thorac. Soc. 2010, 7, 111-115. [CrossRef]

10. DeVries, R.; Kriebel, D.; Sama, S. Outdoor air pollution and copd-related emergency department visits, hospital admissions, and mortality: A meta-analysis. COPD J. Chronic Obstr. Pulm. Dis. 2017, 14, 113-121. [CrossRef]

11. Hackmann, D.; Sjöberg, E. Ambient air pollution and pregnancy outcomes-A study of functional form and policy implications. Air Qual. Atmos. Health 2017, 10, 129-137. [CrossRef]

12. Liu, J.C.; Mickley, L.J.; Sulprizio, M.P.; Dominici, F.; Yue, X.; Ebisu, K.; Anderson, G.B.; Khan, R.F.A.; Bravo, M.A.; Bell, M.L. Particulate air pollution from wildfires in the Western US under climate change. Clim. Chang. 2016, 138, 655-666. [CrossRef]

13. McCreanor, J.; Cullinan, P.; Nieuwenhuijsen, M.J.; Stewart-Evans, J.; Malliarou, E.; Jarup, L.; Harrington, R.; Svartengren, M.; Han, I.-K.; Ohman-Strickland, P.; et al. Respiratory effects of exposure to diesel traffic in persons with asthma. N. Engl. J. Med. 2007, 357, 2348-2358. [CrossRef]

14. Pirozzi, C.S.; Jones, B.E.; VanDerslice, J.A.; Zhang, Y.; Paine, R.; Dean, N.C. Short-term air pollution and incident pneumonia. A case-Crossover study. Ann. Am. Thorac. Soc. 2018, 15, 449-459. [CrossRef]

15. Pirozzi, C.; Mendoza, D.; Xu, Y.; Zhang, Y.; Scholand, M.; Baughman, R. Short-term particulate air pollution exposure is associated with increased severity of respiratory and quality of life symptoms in patients with fibrotic sarcoidosis. Int. J. Environ. Res. Public. Health 2018, 15, 1077. [CrossRef] [PubMed]

16. Mendoza, D.L.; Pirozzi, C.S.; Crosman, E.T.; Liou, T.G.; Zhang, Y.; Cleeves, J.J.; Bannister, S.C.; Anderegg, W.R.L.; Robert, P.I. Impact of low-level fine particulate matter and ozone exposure on absences in K-12 students and economic consequences. Environ. Res. Lett. 2020, 15, 114052. [CrossRef]

17. Tian, Y.; Wu, Y.; Liu, H.; Si, Y.; Wu, Y.; Wang, X.; Wang, M.; Wu, J.; Chen, L.; Wei, C.; et al. The impact of ambient ozone pollution on pneumonia: A nationwide time-series analysis. Environ. Int. 2020, 136, 105498. [CrossRef] [PubMed]

18. Landrigan, P.J.; Fuller, R.; Acosta, N.J.R.; Adeyi, O.; Arnold, R.; Basu, N.; Baldé, A.B.; Bertollini, R.; Bose-O'Reilly, S.; Boufford, J.I.; et al. The lancet commission on pollution and health. Lancet 2018, 391, 462-512. [CrossRef]

19. Landrigan, P.J.; Fuller, R.; Fisher, S.; Suk, W.A.; Sly, P.; Chiles, T.C.; Bose-O'Reilly, S. Pollution and children's health. Sci. Total Environ. 2019, 650, 2389-2394. [CrossRef]

20. Payne-Sturges, D.C.; Marty, M.A.; Perera, F.; Miller, M.D.; Swanson, M.; Ellickson, K.; Cory-Slechta, D.A.; Ritz, B.; Balmes, J.; Anderko, L.; et al. Healthy air, healthy brains: Advancing air pollution policy to protect children's health. Am. J. Public Health 2019, 109, 550-554. [CrossRef] [PubMed]

21. Quaderi, S.A.; Hurst, J.R. The unmet global burden of COPD. Glob. Health Epidemiol. Genom. 2018, 3, e4. [CrossRef]

22. Brook, R.D.; Brook, J.R.; Urch, B.; Vincent, R.; Rajagopalan, S.; Silverman, F. Inhalation of fine particulate air pollution and ozone causes acute arterial vasoconstriction in healthy adults. Circulation 2002, 105, 1534-1536. [CrossRef]

23. Hall, S.J.; Maurer, G.; Hoch, S.W.; Taylor, R.; Bowling, D.R. Impacts of anthropogenic emissions and cold air pools on urban to montane gradients of snowpack ion concentrations in the Wasatch Mountains, Utah. Atmos. Environ. 2014, 98, 231-241. [CrossRef]

24. Skiles, S.M.; Painter, T.H.; Deems, J.S.; Bryant, A.C.; Landry, C.C. Dust radiative forcing in snow of the upper colorado river basin: 2. Interannual variability in radiative forcing and snowmelt rates: Dust radiative forcing snowmelt response. Water Resour. Res. 2012, 48, 1-11. [CrossRef]

25. Bekkar, B.; Pacheco, S.; Basu, R.; DeNicola, N. Association of air pollution and heat exposure with preterm birth, low birth weight, and stillbirth in the US: A systematic review. JAMA Netw. Open 2020, 3, e208243. [CrossRef]

26. Adler, N.E.; Newman, K. Socioeconomic disparities in health: Pathways and policies. Health Aff. 2002, 21, 60-76. [CrossRef]

27. Backlund, E.; Sorlie, P.D.; Johnson, N.J. A comparison of the relationships of education and income with mortality: The national longitudinal mortality study. Soc. Sci. Med. 1999, 49, 1373-1384. [CrossRef]

28. Wilkinson, R.G. Unhealthy Societies; Routledge: London, UK, 1992; ISBN 978-1-134-87280-0.

29. Kaplan, G.A.; Pamuk, E.R.; Lynch, J.W.; Cohen, R.D.; Balfour, J.L. Inequality in income and mortality in the United States: Analysis of mortality and potential pathways. BMJ 1996, 312, 999-1003. [CrossRef] 
30. Kennedy, B.P.; Kawachi, I.; Prothrow-Stith, D.; Lochner, K.; Gupta, V. Social capital, income inequality, and firearm violent crime. Soc. Sci. Med. 1998, 47, 7-17. [CrossRef]

31. Stiglitz, J.E.; Fitoussi, J.-P.; Durand, M. Beyond GDP: Measuring What Counts for Economic and Social Performance; OECD: Paris, France, 2018; ISBN 978-92-64-30728-5.

32. Winkleby, M.A.; Jatulis, D.E.; Frank, E.; Fortmann, S.P. Socioeconomic status and health: How education, income, and occupation contribute to risk factors for cardiovascular disease. Am. J. Public Health 1992, 82, 816-820. [CrossRef]

33. Perera, F. Pollution from fossil-fuel combustion is the leading environmental threat to global pediatric health and equity: Solutions exist. Int. J. Environ. Res. Public. Health 2017, 15, 16. [CrossRef] [PubMed]

34. HEI Panel on the Health Effects of Traffic-Related Air Pollution. Traffic-Related Air Pollution: A Critical Review of the Literature on Emissions, Exposure and Health Effects; Health Effects Institute: Boston, MA, USA, 2010.

35. Zigler, C.M.; Choirat, C.; Dominici, F. Impact of national ambient air quality standards nonattainment designations on particulate pollution and health. Epidemiology 2018, 29, 165-174. [CrossRef]

36. Trasande, L.; Sathyanarayana, S.; Messito, M.J.; Gross, R.S.; Attina, T.M.; Mendelsohn, A.L. Phthalates and the diets of US children and adolescents. Environ. Res. 2013, 126, 84-90. [CrossRef] [PubMed]

37. Bell, M.L.; Ebisu, K. Environmental inequality in exposures to airborne particulate matter components in the United States. Environ. Health Perspect. 2012, 120, 1699-1704. [CrossRef] [PubMed]

38. Clark, L.P.; Millet, D.B.; Marshall, J.D. National patterns in environmental injustice and inequality: Outdoor $\mathrm{NO}_{2}$ air pollution in the United States. PLoS ONE 2014, 9, e94431. [CrossRef]

39. World Health Organization. Social Determinants of Health. Available online: https://www.who.int/westernpacific/healthtopics/social-determinants-of-health (accessed on 11 September 2021).

40. U.S. Department of Health and Human Services. The Secretary's Advisory Committee on National Health Promotion and Disease Prevention Objectives for 2020. Phase I Report: Recommendations for the Framework and Format of Healthy People 2020; U.S. Department of Health and Human Services: Washington, DC, USA, 2010; p. 28.

41. Singh, G.; Daus, G.; Allender, M.; Ramey, C.; Martin, E.; Perry, C.; Reyes, A.; Vedamuthu, I. Social determinants of health in the United States: Addressing major health inequality trends for the nation, 1935-2016. Int. J. MCH AIDS IJMA 2017, 6, 139-164. [CrossRef]

42. McGinnis, J.M.; Williams-Russo, P.; Knickman, J.R. The case for more active policy attention to health promotion. Health Aff. 2002, 21, 78-93. [CrossRef]

43. Vrijheid, M. The exposome: A new paradigm to study the impact of environment on health. Thorax 2014, 69, 876-878. [CrossRef]

44. Garcia, E.; Weiss, E. Student Absenteeism: Who Misses School and How Missing School Matters for Performance. Available online: https:/ / www.epi.org/publication/student-absenteeism-who-misses-school-and-how-missing-school-matters-forperformance/ (accessed on 19 October 2021).

45. Yang, J.; Zheng, Y.; Gou, X.; Pu, K.; Chen, Z.; Guo, Q.; Ji, R.; Wang, H.; Wang, Y.; Zhou, Y. Prevalence of comorbidities and its effects in patients infected with SARS-CoV-2: A systematic review and meta-analysis. Int. J. Infect. Dis. 2020, 94, 91-95. [CrossRef]

46. Shin, M.; Werner, A.; Strosnider, H.; Hines, L.; Balluz, L.; Yip, F. Public perceptions of environmental public health risks in the United States. Int. J. Environ. Res. Public Health 2019, 16, 1045. [CrossRef]

47. Reames, T.G.; Bravo, M.A. People, place and pollution: Investigating relationships between air quality perceptions, health concerns, exposure, and individual- and area-level characteristics. Environ. Int. 2019, 122, 244-255. [CrossRef] [PubMed]

48. Bickerstaff, K. Risk perception research: Socio-cultural perspectives on the public experience of air pollution. Environ. Int. 2004, 30, 827-840. [CrossRef]

49. Bell, M.L.; O'Neill, M.S.; Cifuentes, L.A.; Braga, A.L.F.; Green, C.; Nweke, A.; Rogat, J.; Sibold, K. Challenges and recommendations for the study of socioeconomic factors and air pollution health effects. Environ. Sci. Policy 2005, 8, 525-533. [CrossRef]

50. Lipka, M.; Wormald, B.; Most and Least Religious U.S. States. Available online: https://www.pewresearch.org/fact-tank/2016/0 2/29/how-religious-is-your-state/?state=alabama (accessed on 19 October 2021).

51. Newport, F. Mississippi Retains Standing as Most Religious State. Available online: https://news.gallup.com/poll/203747 /mississippi-retains-standing-religious-state.aspx (accessed on 11 September 2021).

52. White, L. The historical roots of our ecologic crisis. Science 1967, 155, 1203-1207. [CrossRef] [PubMed]

53. Boyd, H.H. Christianity and the environment in the american public. J. Sci. Study Relig. 1999, 38, 36. [CrossRef]

54. Eckberg, D.L.; Blocker, T.J. Varieties of religious involvement and environmental concerns: Testing the lynn white thesis. J. Sci. Study Relig. 1989, 28, 509. [CrossRef]

55. Arbuckle, M.B.; Konisky, D.M. The role of religion in environmental attitudes: Role of religion in environmental attitudes. Soc. Sci. Q. 2015, 96, 1244-1263. [CrossRef]

56. Colmer, J.; Hardman, I.; Shimshack, J.; Voorheis, J. Disparities in $\mathrm{PM}_{2.5}$ air pollution in the United States. Science 2020, 369, 575-578. [CrossRef] [PubMed]

57. Hajat, A.; Hsia, C.; O’Neill, M.S. Socioeconomic disparities and air pollution exposure: A global review. Curr. Environ. Health Rep. 2015, 2, 440-450. [CrossRef] [PubMed]

58. Mohai, P.; Pellow, D.; Roberts, J.T. Environmental justice. Annu. Rev. Environ. Resour. 2009, 34, 405-430. [CrossRef]

59. Shmueli, D.F. Environmental justice in the israeli context. Environ. Plan. Econ. Space 2008, 40, 2384-2401. [CrossRef] 
60. Omer, I.; Or, U. Distributive environmental justice in the city: Differential access in two mixed israeli cities. Tijdschr. Voor Econ. En Soc. Geogr. 2005, 96, 433-443. [CrossRef]

61. McCright, A.M.; Dunlap, R.E. The politicization of climate change and polarization in the american public's views of global warming, 2001-2010. Sociol. Q. 2011, 52, 155-194. [CrossRef]

62. Gregersen, T.; Doran, R.; Böhm, G.; Tvinnereim, E.; Poortinga, W. Political orientation moderates the relationship between climate change beliefs and worry about climate change. Front. Psychol. 2020, 11, 1573. [CrossRef]

63. Hu, S.; Jia, X.; Zhang, X.; Zheng, X.; Zhu, J. How political ideology affects climate perception: Moderation effects of time orientation and knowledge. Resour. Conserv. Recycl. 2017, 127, 124-131. [CrossRef]

64. Pew Reserach Center. Trends in Party Affiliation among Demographic Groups; Pew Research Center: Washington, DC, USA, 2018.

65. Benney, T.; Chaney, R.; Singer, P.; Sloan, C. Utah Air Quality Risk and Behavioral Action Survey 2019. Available online: https://www.openicpsr.org/openicpsr/project/117904/version/V1/view (accessed on 18 October 2021).

66. Kem, C. Gardner Policy Institute. Available online: https://gardner.utah.edu/ (accessed on 19 October 2021).

67. Van Buuren, S.; Groothuis-Oudshoorn, K. Mice: Multivariate imputation by chained equations in R. J. Stat. Softw. 2011, 45, 1-67. [CrossRef] 